\title{
Hubert Obora
}

Uniwersytet Ekonomiczny w Krakowie

e-mail:oborah@uek.krakow.pl

\section{ZASADY I NARZĘDZIA REALIZACJI ANALIZY RCA PRINCIPLES AND TOOLS OF RCA ANALYSIS REALIZATION}

DOI: $10.15611 /$ pn.2018.538.24

JEL Classification: M100 Business Administration: General

Streszczenie: Celem niniejszego artykułu jest przedstawienie istoty analizy źródłowych przyczyn problemu (Root Cause Analysis) jako metody mogącej znaleźć swoje zastosowanie w procesie rozwiązywania problemów z obszaru strategicznego zarządzania przedsiębiorstwem. Artykuł rozpoczęto od wskazania zasadności wykorzystywania w procesach zarządzania strategicznego narzędzi analizy problemów. W dalszej kolejności przedstawiono ideę analizy RCA opartą na pojęciu źródłowej przyczyny problemu oraz jej główne założenia. Prezentację głównych założeń RCA rozpoczęto od przedstawiania propozycji układu faz i etapów postępowania charakterystycznych dla tej metody. W ramach przyjętego sposobu postępowania omówiono podstawowe zasady realizacji RCA odnoszące się do poszczególnych faz i etapów postępowania badawczego. Dla każdej z faz postępowania badawczego przedstawiono wybrane techniki pomocnicze, czyniące proces analizy bardziej skutecznym i efektywnym.

Słowa kluczowe: problem, analiza przyczyn, przyczyna źródłowa.

Summary: The aim of this article is to present the essence of the root cause analysis as a method that may be applied in the process of solving problems in the area of strategic business management. The article started from the indication of the legitimacy of using problem analysis tools in strategic management processes. Next, the idea of RCA analysis based on the concept of the root cause of the problem and the main RCA assumptions were presented. The presentation of the main assumptions of the RCA started with the presentation of proposals for the system of phases and stages of conduct characteristic of this method. Within the framework of the method of conduct adopted, the basic principles of RCA implementation

related to individual phases and stages of the research procedure were discussed. For each of the phases of the research procedure selected auxiliary techniques making the analysis process more effective were presented.

Keywords: problem, cause analysis, root cause. 


\section{Wstęp}

Zarządzanie strategiczne, stanowiące jeden z najistotniejszych z praktycznego punktu widzenia obszarów zarządzania przedsiębiorstwem, podlega ciągłej ewolucji. Biorąc pod uwagę jego główny cel, jakim jest dążenie do ograniczania niepewności oraz poszukiwanie i dostarczenie narzędzi działania, które ułatwią zarządzanie rozwojem przedsiębiorstwa, można stwierdzić, że jest ono ściśle uzależnione od zmian mających miejsce nie tylko w samym przedsiębiorstwie, lecz także w jego otoczeniu. Jednym z kanonów współczesnego zarządzania strategicznego jest nie tylko koncentrowanie się na już istniejących $\mathrm{w}$ otoczeniu przeobrażeniach, lecz przede wszystkim budowanie zdolności antycypowania przyszłych zmian [Sopińska, Wachowiak 2017, s. 4]. Szybkość, z jaką pojawiają się zmiany zarówno w przedsiębiorstwie, jak i jego otoczeniu, powoduje powstanie wielu problemów, m.in. w obszarach projektowania, przygotowania, realizacji i oceny strategii przedsiębiorstwa. $\mathrm{Z}$ drugiej strony coraz większy stopień skomplikowania procesów realizowanych we współczesnych przedsiębiorstwach powoduje, że analiza zmian wymaga coraz szerszego podejścia, angażującego różne stanowiska, postawy, punkty widzenia, przekroje wiedzy itp. W niniejszym artykule przedstawiono istotę jednej ze współczesnych metod wielopłaszczyznowej analizy problemu jako narzędzia mogącego być wykorzystywanym w procesie rozwiązywania problemów obszaru zarządzania strategicznego. Metodą tą jest analiza źródłowych przyczyn problemu RCA (Root Cause Analysis), którą w obszarze zarządzania strategicznego wykorzystać można jako narzędzie rozwiązywania problemów związanych z projektowaniem, realizacją i oceną strategii przedsiębiorstwa (organizacji). W dzisiejszym świecie liczba czynników, które mogą negatywnie oddziaływać na procesy związane z opracowywaniem, realizacją czy oceną strategii firmy, jest bardzo duża i stale rośnie. Czynniki te tkwią zarówno w przedsiębiorstwie, jak i w jego bliższym i dalszym otoczeniu. Metodę RCA wykorzystać można jako jedno z narzędzi analizy tych czynników pod kątem możliwości ich eliminacji czy też zmniejszenia negatywnego stopnia oddziaływania na procesy związane z zarządzaniem strategicznym. Opisywana metoda może stanowić ciekawą alternatywę lub wsparcie dla takich technik wykorzystywanych w analizie strategicznej, jak analiza martwych pól czy analiza drzewa błędów.

RCA ukierunkowana jest na identyfikowanie źródeł przyczyn pojawiających się problemów lub zdarzeń. Jej skuteczność wynika z założenia, że eliminować należy rzeczywiste przyczyny problemów, a nie oczywiste ich symptomy. Przez dedykowanie działań naprawczych i odpowiednich związanych z nimi środków we właściwe miejsca można spodziewać się, że prawdopodobieństwo powtarzania się problemu zostanie zminimalizowane (choć w wielu przypadkach niewykluczone). W przeciwieństwie do zwykłego przeglądu objawów zdarzeń, RCA podchodzi do ich analizy na drodze identyfikacji i eliminacji przyczyn źródłowych [Barsalou 2015, s. 7]. Mianem przyczyny źródłowej problemu określa się najbardziej szkodliwy czynnik, warunek, zachowanie, działanie i/lub brak działania, które przejawiają się poprzez 
co najmniej jeden istotny skutek tego problemu, niebędący z kolei rezultatem ważniejszych, bardziej podstawowych warunków, zachowań, działań i/lub braku działań [Andersen, Fagerhaug 2006, s. 12].

Analiza przyczyn źródłowych nie jest jednorodną, szczegółowo zdefiniowaną metodą. W literaturze przedmiotu niewiele jest publikacji na jej temat, natomiast w praktyce jej stosowania istnieje wiele różnych podejść, narzędzi, procesów i filozofii. Przedstawiony w dalszej części opracowania tok postępowania badawczego, zbiór zasad i narzędzi realizacji RCA jest propozycją wynikającą z doświadczenia autora w projektach wykorzystujących założenia tej metody. Postępowanie charakterystyczne dla analizy źródłowych przyczyn problemu można podzielić na trzy podstawowe fazy:

1. Przygotowanie do RCA.

2. Realizacja RCA.

3. Wykorzystanie wyników RCA.

Podział ten jest umowny, a w praktyce funkcjonuje wiele różnych podejść zróżnicowanych pod względem szerokości ujęcia, celów zastosowania czy wykorzystywanego zbioru narzędzi pomocniczych.

\section{Przygotowanie do analizy RCA}

Celem pierwszej fazy RCA jest przygotowanie danych wejściowych do procesu poszukiwania źródłowych przyczyn problemu. Prawidłowa realizacja tej fazy postępowania jest szczególnie istotna, ponieważ od jakości zgromadzonych w niej informacji zależy powodzenie dalszej części RCA. Przygotowanie do RCA sprowadza się do realizacji pięciu podstawowych etapów. Są to:

1. Identyfikacja problemu.

2. Formowanie się zespołu projektowego.

3. Zbieranie informacji o problemie.

4. Dokonanie charakterystyki problemu w oparciu o zebrane informacje.

5. Opracowanie listy potencjalnych przyczyn problemu.

Identyfikacja problemu sprowadza się do jego sformułowania w postaci zdania lub równoważnika zdania (np. ginące karty kanban, brak realizacji w założonym czasie działań poaudytowych). Problemy mogą być identyfikowane przez pracowników przedsiębiorstwa, jego klientów, dostawców czy kooperantów. Osoba identyfikująca problem rozpoczyna jego analizę od odpowiedzi na pytanie, czy samodzielnie jest w stanie go rozwiązać. W wielu przypadkach odpowiedź jest twierdząca i wtedy nie ma konieczności stosowania wymagającej czasu i podejścia zespołowego analizy RCA. Inaczej jest w przypadku, w którym identyfikujący problem stwierdza, że nie jest w stanie rozwiązać go samodzielnie ze względu na niewystarczającą wiedzę, umiejętności czy możliwości decyzyjne związane z miejscem zajmowanym w strukturze organizacyjnej przedsiębiorstwa. W takiej sytuacji wykorzystać należy jedną z form zespołowego rozwiązywania problemów, a większość ze stosowanych obecnie zawiera analizę RCA [Andersen, Fagerhaug 2006, s. 8]. 
Jednym z krytycznych punktów RCA jest dobór członków zespołu realizującego analizę. Rozwiązanie problemu wiąże się zawsze z koniecznością zdobycia nowej wiedzy, której źródłem w przedsiębiorstwie są proces, człowiek oraz informacja historyczna (zawarta w dokumentach, zapisach itp.). Ponieważ człowiek jest jednym z najistotniejszych źródeł informacji potrzebnych do rozwiązania problemu, skład zespołu jest jedną z kluczowych kwestii analizy RCA. Aby zebrać odpowiedni skład zespołu, należy zadać dwa zasadnicze pytania:

1. Kto problem zgłasza?

2. Kto jest na tyle blisko problemu, że może mieć wiedzę i umiejętności potrzebne do jego rozwiązania?

W zespole RCA warto mieć osobę znającą skutki problemu i mogącą nakreślić innym jego rangę. Najistotniejszą jednak kwestią jest zebranie w składzie zespołu osób znających problem, ale widzących go z różnych perspektyw. To wymaganie zostaje spełnione, kiedy zespół RCA jest interdyscyplinarny, tzn. obejmuje reprezentantów różnych funkcji i dziedzin działania przedsiębiorstwa (związanych $\mathrm{z}$ badanym problemem). Zespół realizujący analizę RCA liczy przeważnie 2-4 osoby, choć zdarzają się przypadki, w których skład zespołu to nawet 10-12 osób [Vorley 2008, s. 3]. Po zorganizowaniu się zespół przystępuje do pracy.

Kolejną istotną kwestią związaną z przygotowaniem do RCA jest zebranie danych charakteryzujących problem i opracowanie w oparciu o nie jego opisu. Uczestnicy zespołu starają się zebrać maksymalnie dużo informacji związanych z problemem. Powinny być to zarówno informacje skwantyfikowane (w formie liczb, wskaźników itp.), jak i informacje opisowe. Zebrane informacje są wykorzystywane do opracowania opisu (charakterystyki) problemu. Charakterystyka problemu zawiera informacje na temat zdarzeń, które miały miejsce, czasu, w którym one wystąpiły, miejsca ich pojawienia się oraz skutków tych zdarzeń (w szczególności związanych z nimi strat). Opracowywanie przez zespół charakterystyki problemu jest świetnym przyczynkiem do dyskusji prowadzonej przez osoby reprezentujące różne punkty widzenia na ten problem. Taka wymiana informacji powoduje nie tylko uzgodnienie punktów widzenia, lecz także powstanie efektu synergii na skutek zderzenia z sobą różnorodnych postaw, wiedzy i umiejętności członków zespołu. Głównym celem tworzenia charakterystyki problemu jest zebranie, a następnie przekazanie uczestnikom zespołu (oraz wymiana pomiędzy nimi) najszerszej możliwej informacji na temat rozwiązywanego problemu. Informacja ta pozwala na opracowanie przez zespół możliwie jak najszerszej listy potencjalnych przyczyn problemu. W tym celu wykorzystuje się najczęściej jedną z odmian burzy mózgów. Zasada opracowania listy potencjalnych przyczyn problemu jest prosta - każdy z członków zespołu wykorzystując zdobytą do tej pory wiedzę, powinien zgłosić jak najwięcej możliwych do zaistnienia przyczyn. Pomysły członków zespołu są zbierane na jednej liście i stanowią zbiór danych wejściowych do następnej fazy RCA - właściwej analizy [Root Cause 2015, s. 15]. Aby maksymalnie skrócić i uprościć fazę przygotowania do RCA, można wykorzystać narzędzie pomocnicze określane mianem analizy IS/IS NOT [Dogget 2006, s. 36]. Technika ta oparta jest na 
scenariuszu pytań, na które odpowiedzi pozwalają sformować zespół RCA, następnie przeprowadzić w jego ramach dyskusję skutkującą opracowaniem charakterystyki problemu i wreszcie opracować listę potencjalnych przyczyn problemu. Strukturę pytań zadawanych w ramach analizy IS/IS NOT zawiera tabela 1.

Tabela 1. Struktura pytań analizy IS/IS NOT

\begin{tabular}{|l|l|l|l|}
\hline Lp. & Pytanie & \multicolumn{1}{|c|}{ IS } & \multicolumn{1}{c|}{ IS NOT } \\
\hline 1 & Who? & $\begin{array}{l}\text { Kogo problem dotyka? } \\
\text { Kto problem zgłasza? }\end{array}$ & $\begin{array}{l}\text { Kogo problem nie dotyka? } \\
\text { Kto problemu nie zgłasza? }\end{array}$ \\
\hline 2 & What? & $\begin{array}{l}\text { Co się dzieje? } \\
\text { Co jest problemem? } \\
\text { Na czym polega problem? }\end{array}$ & $\begin{array}{l}\text { Co nie jest problemem? } \\
\text { Co się mogło wydarzyć, } \\
\text { ale się nie wydarzyło? }\end{array}$ \\
\hline 3 & $\begin{array}{l}\text { How } \\
\text { many? }\end{array}$ & $\begin{array}{l}\text { Jakie są rozmiary problemu? } \\
\text { Ile problem kosztuje? }\end{array}$ & $\begin{array}{l}\text { Jakie mogłyby być rozmiary problemu, } \\
\text { ale nie są? } \\
\text { Ile problem mógłby kosztować, } \\
\text { ale nie kosztuje? }\end{array}$ \\
\hline 4 & When? & $\begin{array}{l}\text { Kiedy problem odkryto po raz pierwszy? } \\
\text { Kiedy pojawił się od tego czasu? }\end{array}$ & $\begin{array}{l}\text { Kiedy problem powinien być odkryty, } \\
\text { ale tak się nie stało? }\end{array}$ \\
\hline 5 & Where? & $\begin{array}{l}\text { Gdzie problem powstał? } \\
\text { Gdzie problem wykryto? }\end{array}$ & $\begin{array}{l}\text { Gdzie problem mógł powstać, } \\
\text { ale nie powstał? } \\
\text { Gdzie problem mógł być wykryty, } \\
\text { ale nie został? }\end{array}$ \\
\hline 6 & Why? & Co spowodowało powstanie problemu? & $\begin{array}{l}\text { Co nie spowodowało powstania } \\
\text { problemu? }\end{array}$ \\
\hline
\end{tabular}

Źródło: opracowanie własne na podstawie [Dogget 2006, s. 36].

Celem odpowiedzi na pytanie 1. (who?) jest dokonanie wyboru najlepszego możliwego składu zespołu RCA. Pytania 2. i 3. (what i how many?) służą do ustalenia, na czym polega problem i jakie są jego skutki. Kolejne dwa pytania (4. i 5.) mają dostarczyć wiedzy dotyczącej czasu i miejsca (lub miejsc) pojawienia się problemu. Ostatnie z pytań (why?) służy zespołowi do opracowania listy potencjalnych przyczyn analizowanego problemu. Istotnym założeniem metody jest równoległe zadawanie pytań przeciwnych (IS - IS NOT). Przykładowo: odpowiadając na pytanie 5. (where), uczestnicy z jednej strony wskazują miejsca, w których problem powstał, z drugiej natomiast te, w których na pewno go nie zidentyfikowano. Takie ujęcie pozwala na lepsze zrozumienie charakteru problemu oraz jego mechanizmu. Lista potencjalnych przyczyn problemu będąca odpowiedzią na ostatnie z pytań analizy IS/IS NOT stanowi dane wejściowe do drugiej fazy RCA.

\section{Realizacja RCA}

Faza pierwsza RCA była jedynie przygotowaniem danych do właściwego postępowania RCA, będącego treścią fazy drugiej. Jej celem jest odnalezienie źródłowych 
przyczyn problemu poprzez dogłębne zbadanie i zrozumienie mechanizmów jego powstania. W ramach tej fazy postępowania realizowane są następujące etapy działania:

1. Redukcja listy potencjalnych przyczyn problemu.

2. Identyfikacja przyczyn źródłowych problemu.

3. Weryfikacja przyczyn źródłowych problemu.

Redukcja listy potencjalnych przyczyn problemu ma na celu wybranie przez zespół do dalszej analizy jedynie tych przyczyn, których wpływ na problem jest znaczący. Zgodnie z zasadą Pareto $20 \%$ najważniejszych przyczyn problemu wpływa w $80 \%$ na jego skutki. Wynika z tego, że przeciwdziałanie problemowi może zawęzić się do odziaływania na stosunkowo niewielką liczbę przyczyn, skracając czas analiz i zmniejszając koszty ewentualnych działań naprawczych [Vorley 2008, s. 7]. Jednym z narzędzi, jakie można wykorzystać do redukcji listy potencjalnych przyczyn problemu, jest technika 4M. Technika ta w swoich głównych założeniach jest zbliżona do powszechnie znanego i stosowanego narzędzia jakości określanego mianem diagramu Ishikawy. Zastosowanie 4M sprowadza się do podziału listy przyczyn problemu na logicznie wyodrębnione grupy, a następnie na podstawie analizy każdej z nich wyboru przyczyn do dalszego postępowania [Dogget 2006, s. 35]. Skrót 4M oznacza 4 zbiory, w ramach których klasyfikowane są przyczyny z listy: metoda (Method), maszyna (Machine), człowiek (Man) i materiał (Material). Strukturę tych 4 zbiorów przedstawia tabela 2. Pierwsza ze wskazanych grup obejmuje przyczyny związane ze stosowanymi w przedsiębiorstwie metodami pracy (zarówno tymi sformalizowanymi w postaci procedur i instrukcji, jak i tymi, które nie są sformalizowane, ale pracownicy zwyczajowo je stosują). Grupa druga to przyczyny związane ze stosowaną techniką (maszynami, urządzeniami, narzędziami itp.). Kolejna to przyczyny związane z człowiekiem, czyli błędy ludzkie. Ostatnia z grup przyczyn rozpatrywana w technice 4M to przyczyny leżące po stronie wykorzystywanych materiałów, np. nieodpowiednia twardość czy za niska wytrzymałość na zgniatanie.

Tabela 2. Klasyfikacja przyczyn w technice 4M

\begin{tabular}{|c|l|}
\hline \multicolumn{1}{|c|}{ Metoda } & \multicolumn{1}{|c|}{ Maszyna } \\
\hline Przyczyna 1 & Przyczyna 1 \\
Przyczyna 2 & Przyczyna 2 \\
Przyczyna 3 & Przyczyna 3 \\
\hline \multicolumn{1}{|c|}{ Człowiek } & \multicolumn{1}{|c|}{ Materiał } \\
\hline Przyczyna 1 & Przyczyna 1 \\
Przyczyna 2 & Przyczyna 2 \\
Przyczyna 3 & Przyczyna 3 \\
\hline
\end{tabular}

Źródło: opracowanie własne na podstawie [Dogget 2006, s. 35-36].

Pogrupowanie przyczyn z zastosowaniem 4M jest punktem wyjścia do ich dalszej analizy. W dalszej kolejności uczestnicy wybierają lub losują dla siebie jedną z 4 kategorii, a następnym ich zadaniem jest zdobycie informacji na temat przyczyn 
w wylosowanej grupie. Poszczególni członkowie zespołu szukają informacji potwierdzających lub negujących przyczyny w wylosowanym przez siebie zbiorze, a także tych mówiących o stopniu, w jakim dana przyczyna może wpływać na problem. Dane te pozyskuje się z trzech źródeł: obserwacji procesów, rozmów ze specjalistami oraz danych historycznych w postaci dokumentacji i zapisów. Zdobyte w ten sposób informacje są referowane $\mathrm{w}$ trakcie spotkania zespołu RCA, a następnie poddawane dyskusji prowadzącej do wyboru najbardziej istotnych z punktu widzenia wpływu na problem. Wybór może nastąpić na drodze zwykłej dyskusji bądź też dzięki zastosowaniu techniki grupy eksperckiej lub wykresu Pareto. W celu zastosowania wykresu Pareto wykorzystuje się zebrane wcześniej charakterystyki liczbowe przyczyn lub (jeśli ich zebranie nie jest możliwe) oceny punktowe przyczyn uzyskane dzięki zastosowaniu przez uczestników odpowiednio dobranej skali ocenowej. Ten drugi przypadek określa się jako wartościowanie przyczyn przez zespół.

Kolejnym etapem w ramach drugiej fazy RCA jest identyfikacja przyczyn źródłowych. Dokonuje się jej jedynie dla przyczyn wybranych w etapie poprzednim. Jeśli przyjmiemy, że przyczyną problemu jest czynnik lub zespół warunków powodujących jego określone skutki, to należy zauważyć, że przyczyny oprócz wpływu na problem mogą również wywierać wpływ na siebie, np. znosząc się lub wzmacniając. Należy również podkreślić, że przyczyna problemu może mieć swoją przyczynę (jest to zatem przyczyna przyczyny problemu), ta może mieć swoją (jest to przyczyna przyczyny przyczyny problemu) itd. Opisaną sytuację obrazuje rysunek 1 .

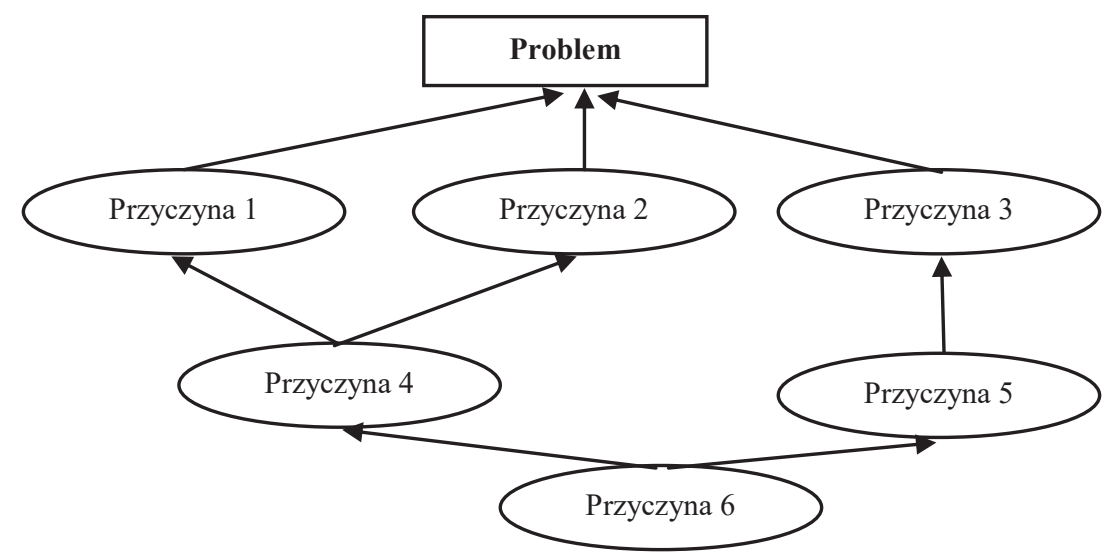

Rys. 1. Zależności pomiędzy przyczynami problemu

Źródło: opracowanie własne.

Przedstawiony na rysunku 1. problem ma 6 przyczyn, ale eliminacja tylko jednej z nich może doprowadzić do jego rozwiązania. Eliminując przyczyny wpływające na problem bezpośrednio (przyczyny 1, 2 i 3), uwolnimy się od niego tylko na jakiś czas, a to dlatego, że eliminując je, pozostawiliśmy ich źródła (przyczyny 4 i 5). 
Podobnie w przypadku przyczyn 4 i 5, których źródłem jest przyczyna 6. Analizując rysunek, możemy dojść do wniosku, że problem rozwiązać można, eliminując przyczynę numer $6, i$ to właśnie ona jest przyczyną źródłową tego problemu. W praktyce do poszukiwania źródłowych przyczyn problemu stosuje się jedną z odmian metody 5 why [Root Cause 2015, s. 29]. Najczęściej jest to wersja klasyczna, choć obecnie coraz częściej wykorzystywane są jej nowsze odmiany: Failure Tree Analysis (analiza drzewa błędów) oraz Drill Deep and Wide (drąż głęboko i szeroko). Na szczególną uwagę ze względu na szerokość ujęcia zasługuje ostatnia ze wskazanych metod. Główne jej założenia wynikają wprost z klasycznej wersji 5 why, a obrazuje je układ stadiów charakterystyczny dla tej metody [Obora 2010, s. 229]:

1. Zbieranie informacji o pojawiającym się problemie.

2. Tworzenie grupy roboczej dla rozwiązania problemu.

3. Sformułowanie problemu w prosty sposób.

4. Przeprowadzenie sesji pytań $5 \times$ X WHY.

5. Przeprowadzenie analizy logiczności wypowiedzi.

6. Określenie przyczyny problemu.

7. Likwidacja przyczyny problemu.

Drill Deep and Wide jest rozszerzeniem analizy 5 why w kierunku poszukiwania trzech rodzajów przyczyn źródłowych związanych z problemem. Po odnalezieniu technicznej przyczyny powstania problemu metoda ta zakłada rozszerzenie analizy 5 why o [RCA 2018, s. 86]:

- przyczyny związane z przewidywaniem (dlaczego w procesie planowania nie przewidziano możliwości powstania błędu);

- przyczyny związane zapobieganiem (dlaczego w procesie produkcyjnym nie udało się zapobiec błędowi);

- przyczyny związane z zabezpieczaniem (dlaczego w procesie kontroli jakości nie odseparowano klienta od błędu).

Z powyższego wynika, że zamiast zadać proste pytanie, dlaczego powstał problem, w wersji tej zadaje się równolegle trzy bardziej szczegółowe:

1. Dlaczego nie przewidziano problemu w procesie planowania?

2. Dlaczego nie zapobiegnięto problemowi w procesie wykonania?

3. Dlaczego nie zabezpieczono klienta przed skutkami problemu w procesie kontroli jakości?

Zidentyfikowane za pomoca jednej z odmian metody 5 why przyczyny źródłowe problemu stanowią na tym etapie postępowania jedynie listę propozycji. Aby można je było uznać za faktyczne źródła problemu, należy je zweryfikować poprzez odnalezienie informacji, które te przyczyny potwierdzają. Na tym etapie działania zespół RCA proponuje metody weryfikacji każdej ze stwierdzonych przyczyn źródłowych. Weryfikacja może przyjąć formę eksperymentu, obserwacji procesu, wywiadu z pracownikami lub analizy informacji historycznych zapisanych w dokumentach. Weryfikacja przyczyn źródłowych kończy drugą fazę RCA. 


\section{Wykorzystanie wyników RCA}

W części ujęć teoretycznych ta faza postępowania nie jest w ogóle brana pod uwagę jako element RCA. W podejściach tego typu analiza kończy się wskazaniem listy źródłowych przyczyn problemu, w praktyce jednak takie podejście jest niewystarczające, ponieważ bardzo istotną kwestią RCA jest sposób wykorzystania jej wyników. W ramach tej fazy postępowania badawczego wyróżnić można następujące etapy:

1. Przygotowanie i wdrożenie rozwiązań problemu.

2. Ocena skuteczności rozwiązań.

3. Standaryzacja rozwiązań.

Rozwiązanie problemu z zastosowaniem RCA polega na opracowaniu i wdrożeniu działań eliminujących jego źródłowe przyczyny. Opracowanie takich działań nie zawsze jest proste, ponieważ dla niektórych przyczyn zaproponować można więcej niż jedno skuteczne rozwiązanie. Jeśli w przypadku określonej przyczyny problemu rozwiązań może być więcej, do opracowania ich listy oraz wyboru rozwiązania do wdrożenia posłużyć może któraś z odmian burzy mózgów (np. Philips 623, Trigger Method czy Meta Plan). W ramach tego etapu postępowania zastosować można jedną z najprostszych i najkrótszych odmian burzy mózgów - Trigger Method, na którą składają się następujące działania [Wodecka-Hyjek 1999, s. 9]:

1. Zapoznanie się zespołu z przyczyną, dla której będzie poszukiwane rozwiązanie.

2. Zapisywanie w ciszy przez ok. 5 minut swoich pomysłów przez każdego członka zespołu.

3. Przedstawienie kolejno przez każdego z członków swoich pomysłów pozostałym.

4. Debata grupy (10 minut) na temat przedstawionych propozycji pod kątem wprowadzenia modyfikacji, a nawet nowych pomysłów.

Proces opracowania rozwiązań w oparciu o tę metodę jest zadaniem stosunkowo prostym. Na uwagę zasługuje natomiast proces wyboru najlepszego rozwiązania (lub rozwiązań) realizowany w ramach etapu czwartego. Aby dokonać wyboru, należy zgłoszone w etapie 3 propozycje rozwiązań ocenić. Ocena taka sprowadza się do odpowiedzi na następujące pytania:

1. Czy oceniane rozwiązanie jest technicznie możliwe do wdrożenia.

2. Czy oceniane rozwiązanie jest ekonomicznie uzasadnione.

3. Czy oceniane rozwiązania jest politycznie poprawne (nie godzi w ważne zasady kultury organizacyjnej przedsiębiorstwa).

Dla wybranych przez członków zespołu rozwiązań problemu przygotowuje się w dalszej kolejności harmonogram ich wdrożenia, zakładający m.in. etapy procesu wdrożenia, czas ich realizacji oraz odpowiedzialne za tę realizację osoby. Najczęstszą techniką służącą opracowaniu harmonogramu wdrożenia rozwiązań jest tzw. Action Plan [Ćwiklicki, Obora 2009, s. 98]. Jest to rodzaj tabeli zawierający najbardziej istotne założenia związane z wdrażanymi rozwiązaniami (zob. tab. 3). 
Tabela 3. Struktura Action Planu

\begin{tabular}{|l|l|l|l|l|l|}
\hline $\begin{array}{l}\text { Przyczyny } \\
\text { źódłowe }\end{array}$ & $\begin{array}{l}\text { Proponowane } \\
\text { rozwiązania }\end{array}$ & $\begin{array}{l}\text { Działania } \\
\text { wdrożeniowe }\end{array}$ & $\begin{array}{l}\text { Osoba } \\
\text { odpowiedzialna }\end{array}$ & $\begin{array}{l}\text { Terminy } \\
\text { zakończenia } \\
\text { działań }\end{array}$ & Uwagi \\
\hline & & & & & \\
\hline & & & & & \\
\hline
\end{tabular}

Źródło: opracowanie własne na podstawie [Obora 2010, s. 331].

Wypełniony Action Plan jest dla członków zespołu RCA podstawą do podjęcia działań wdrożeniowych. Następnym etapem fazy wykorzystania wyników jest ocena wdrożonych rozwiązań. Ocena taka realizowana jest w dwóch płaszczyznach [Obora 2010, s. 330]:

1. Ocena wdrożenia rozwiązań na zgodność z ustaleniami zapisanymi w Action Planie (czy zakładane działania zostały zrealizowane, czy założone terminy ukończenia działań zostały dotrzymane itp.).

2. Ocena skutków wdrożonych rozwiązań (czy i na ile dzięki nim proces został rozwiązany).

Gdy skutki wdrożenia rozwiązań nie są satysfakcjonujące (problem nie został rozwiązany), analizę RCA należy przeprowadzić po raz kolejny, zaczynając od pierwszej fazy. W sytuacji gdy rozwiązania okazały się skuteczne - przechodzi się do ich standaryzacji. Standaryzacja sprowadza się do utrzymania efektów rozwiązania problemu w czasie oraz ewentualnego rozciągnięcia wyników analizy RCA na inne, podobne problemy. Wynikiem końcowym każdej analizy RCA powinien być nowy standard działania odporny na zaistniały, analizowany w ramach tej analizy problem. Taki standard działania przedstawiony pracownikom przedsiębiorstwa zabezpiecza je przed powtórzeniem się przeanalizowanego i rozwiązanego problemu.

\section{Zakończenie}

Zaprezentowana metoda ze względu na swój charakter może stanowić skuteczne i efektywne narzędzie rozwiązywania problemów pojawiających się w procesach związanych ze strategicznym zarządzaniem przedsiębiorstwem. Szczególnie istotnym z tego względu założeniem RCA jest wielopłaszczyznowa ocena problemów przez interdyscyplinarny zespół fachowców reprezentujących różne dziedziny i obszary działalności przedsiębiorstwa zainteresowanych ich rozwiązaniem. Innym założeniem RCA, które może być szczególnie przydatne w analizie problemów zarządzania strategicznego, jest głęboka analiza zarówno czynników wewnętrznych, jak i zewnętrznych w celu poszukiwania źródeł, a nie symptomów tych problemów. Przedstawione $\mathrm{w}$ artykule ujęcie metody jest tylko propozycją, ale propozycją opartą na kilkunastoletnim doświadczeniu autora w stosowaniu tej RCA w przedsiębiorstwach różnych branż i do rozwiązywania problemów związanych z różnymi obszarami funkcjonowania przedsiębiorstwa. 


\section{Literatura}

Andersen B., Fagerhaug T., 2006, Root Cause Analysis: Simplified Tools and Techniques, Second Edition, ASQ Quality Press.

Barsalou M.A., 2015, Root Cause Analysis: A Step-By-Step Guide to Using the Right Tool at the Right Time, CRC Press, New York.

Ćwiklicki M., Obora H., 2009, Metody TQM w zarządzaniu firma, praktyczne przyklady zastosowań, Wydawnictwo Poltext, Warszawa.

Ćwiklicki M., Obora H., 2011, Wprowadzenie do metod TQM, Wydawnictwo Uniwersytetu Ekonomicznego w Krakowie, Kraków.

Dogget A.M., 2006, Root Cause Analysis: A Framework for Tool Selection, Quality Management Journal, no 12 (4), s. 34-45.

Obora H., 2010, Podejście PDCA - Problem Solving w rozwiąywaniu problemów organizacji, Acta Universitatis Lodziensis, Folia Oeconomica, Łódź, s. 323-333.

PDCA Problem Solving Guide, http://www.docstoc.com/docs/3454003/PDCA-Problem-Solving-Guide (7.09.2018).

$R C A, 2018$, materiały szkoleniowe TQMsoft, Kraków.

Root Cause Analysis Following an Event at a Nuclear Installation:Reference Manual, 2015, International Atomic Energy Agency, Viena.

Sopińska A., Wachowiak P. (red.), 2017, Wyzwania współczesnego zarządzania strategicznego, Oficyna Wydawnicza SGH, Warszawa.

Vorley G., 2008, Mini Guide to Root cause Analysis, Quality Management \& Training Ltd, Guildford.

Wodecka-Hyjek A., 1999, Burza mózgów - odmiany i techniki pomocnicze, Problemy Jakości, nr 12, s. $8-11$. 